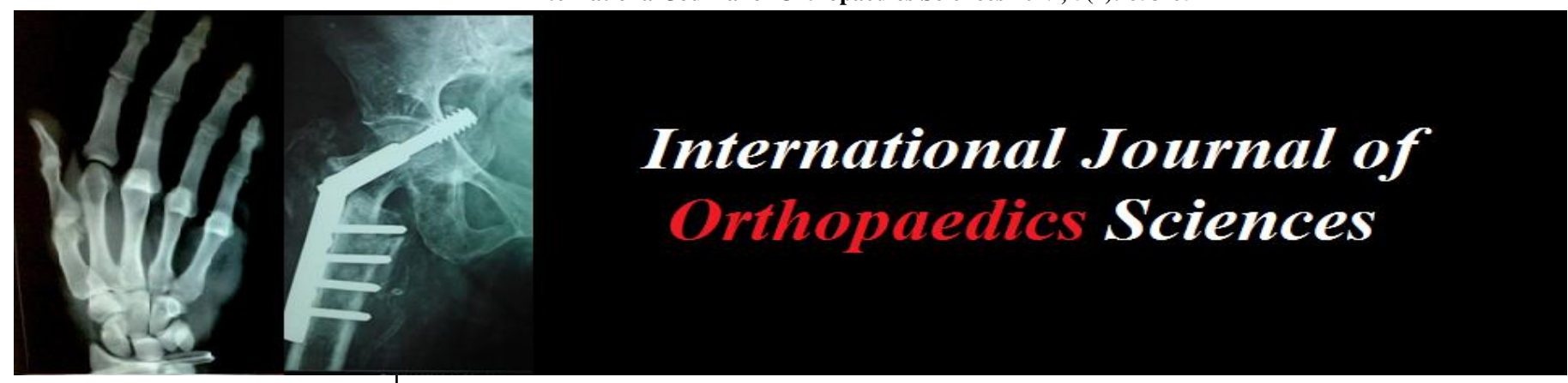

ISSN: $2395-1958$

IJOS 2019; 5(2): 653-657

(C) 2019 IJOS

www.orthopaper.com

Received: 20-02-2019

Accepted: 23-03-2019

Dr. Vijaya Shankar

Associate Professor,

Department Of Orthopedics,

Tagore Medical College,

Tamil Nadu, India

Dr. Kathir Azhagan S

Senior Resident,

Department of Orthopedics,

Tagore Medical College,

Tamil Nadu, India
Correspondence

Dr. Kathir Azhagan S

Senior Resident,

Department of Orthopedics,

Tagore Medical College, India

\section{A study of results of surgical management of distal tibia fractures treated by mippo tehnique with locking compression plate}

\section{Dr. Vijaya Shankar and Dr. Kathir Azhagan S}

DOI: https://doi.org/10.22271/ortho.2019.v5.i2i.67

\section{Abstract}

Background and objectives: The surgical treatment of fractures according to AO principles has seen a change in the past decade, from anatomical reduction and rigid fixation to the current concept of Biological fixation, precise reduction being a goal only in intra-articular fractures. With the advent of internal fixators like PC-Fix and LISS (Less Invasive Stabilizing System) this was being achieved to some extent. The recent development of LCP has revolutionized the treatment by overcoming the few drawbacks of these internal fixators. The LCP is a screw plate system that offers the possibility of inserting conventional and locking head screws into the specially designed combination holes. We aimed to study the nature of fracture union in fractures treated with LCP by MIPO technique and to analyse any complications arising out of this technique.

Methods: This is a retrospective study of 23 cases of distal tibia fracture (19 patients had associated fibula fracture) admitted in Southern Headquarter Railway Hospital, Chennai, between March 2006 and November 2009. Cases were taken according to inclusion and exclusion criteria. We treated all patients with LCP by MIPO technique.

Results: We followed up all the patients and the duration ranged from 13 weeks to 38 weeks (mean 18.9 weeks). All fractures eventually united including 2 which had delayed union. Rest of the 21 fractures united at a mean of 20 weeks. We had totally 6 complications which included superficial infection (1), deep infection (2), iatrogenic fracture (1) and delayed union (2). We had no case of any purely implant related complications like screw loosening, screw breakage, plate failure.

Interpretation and conclusion: The patient sample approximately reflected the regular trauma patients encountered at our set up. Fractures treated with MIPO, healed rapidly by secondary fracture union and hence achieving strong bony union across the facture site. With the LCP system the biological fixation of fractures was easier than the conventional plates. The anchorage of locking head screws even in osteoporotic bone was excellent. We also confirmed its proven efficacy in the treatment of difficult fracture situations, where in other implants have limited application. Fresh conclusions cannot be drawn as sample size is not sufficient.

Keywords: Locking compression plate (LCP), Internal Fixator, Biological fixation

\section{Introduction}

In the recent years road traffic accidents are emerging as one of the leading causes of death in the people with a age group of 15-45 years. Similarly falls are major causes of morbidity and mortality in people above the age of 60years.

In both these groups the patients present with severe or complex injuries. To handle these groups, there has been a constant research with newer modalities of fixation and the birth of the concept of biological fixation.

Intramedullary nails are one of the earliest implants to achieve this concept of biological fixation. But intramedullary devices are not the choice in some fractures, especially those around the joints or those with metaphyseal extensions very close to the joints.

So there was the birth of a new concept of biological fixation using the plates, otherwise called minimally invasive plate osteosynthesis (MIPO). As more and more concepts about biological fixation became clearer the development of internal fixators progressed, leading to development of Less Invasive Stabilising System (LISS), first for distal femur and then for proximal tibia. 
Since still a gap existed between the two principles of conventional plating and the biological plating, there was a need to bridge this gap. Research to combine these two methods or the possibility to combine these two methods has lead to the development of the AO Locking Compression plate (LCP).

This new system has been regarded as technically mature. It offers numerous fixation possibilities and has proven its worth in complex fracture situations and in revision operations after the failure of other implants ${ }^{[1]}$.

\section{Aim and objectives}

1. To study the use of MIPO technique for distal tibia fracture and to asses the clinical and radiological outcome of fracture healing.

2. To study any complications arising with this technique of fracture fixation.

\section{Material and Methodology}

The study was carried out in Southern Headquarter Railway Hospital, Chennai, between March 2006 and November 2009. A total of 23 patients (15 male and 8 female) aged 24 to 70 yrs (mean age 49.4yrs) with fracture of distal tibia (19 patients with associated fracture of fibula) was treated with LCP by MIPO technique.

\section{Exclusion Criteria}

- Patients aged less than $18 y$ rs old

- Compound fractures

- Intra articular fractures of distal tibia

- Pathological fracture

- Nonunion

The study design did not affect the surgeon's choice of treatment or implant.

On admission demographic data was recorded and thorough history and clinical examination was done. We assessed the soft tissue injuries followed by radiological assessment of the fractured limb.

Further investigations were done depending on the general condition of the patient and the routine pre-operative protocol as per our hospital guidelines. Before the surgery, the method of reduction and fixation and the type of implant was provisionally decided.

Depending on the fractured bone, its location (viz. diaphysis or metaphysis) amount of comminution, the associated soft tissue injury etc, the technique of reduction and principle of fixation was decided.

All the patients were treated with Minimally invasive plate osteosynthesis.

\section{Post-Operative}

In the immediate post operative period, care was given to the general condition and fluid balance. Adequate antibiotics were given as per the hospital protocol for orthopaedic surgeries. Oral analgesia was started from $2^{\text {nd }}$ day till adequate pain relief was obtained. This also helped us to mobilize the patients faster.

\section{Mobilization}

External support was given in the form of slab, which was removed intermittently for range of motion (ROM) exercises of neighbouring joints. Partial weight begun after at least first post operative visit, after confirming the beginning of healing process.

\section{Follow UP}

The first follow up was usually between 6-10 weeks and later on patients were followed up at regular intervals of 6-8 weeks till complete fracture union.

During the follow up,

1. The course of fracture healing was documented radiologically (with minimum of 6 weeks between successive radiographs). The moment of complete healing was defined as radiologically complete bone regeneration at the fracture site.

2. Evaluation of any possible loss of reduction that might have occurred, compared to immediate post operative radiographs.

3. Assessment and analysis of any complications observed.

4. Addressing and patients problems, if any.

5. Follow up of our patients ranged from 16 weeks to 64 weeks (mean 28 weeks). No patient was lost to follow up.

\section{Results and discussion}

We studied 23 patients with 23 tibia and 19 patients associated with fibula fractures, who were treated with the locking compression plate by MIPO technique.

Follow up ranged from 3 months to 38 months. Results were assessed both clinically and radilologically. In the final review they were evaluated by Klemm \& Borner functional assessment

In our study we have tried to document the results of LCP by MIPO technique in trauma care. We applied it to heterogenous patient population and across a very mixed spectrum of indications. Our study had broad inclusion and exclusion criteria and the patient population approximately reflected the normal sample of patients at our centre.

We studied 23 patients with fracture of distal tibia (19 patients had associated fracture of fibula). All patients were treated with MIPO technique. For fractures of tibia with associated fibula fracture, fibula was fixed first by open reduction and internal fixation prior to MIPO for tibia fracture.

We stuck to the recommendations and for all locking head screws drilling was done with the screw-in drill sleeve to obtain exact centering and correct orientation of the screw. Hence we did not encounter any loosening of a locking head screw. Neither there was any screw breakage. We also made sure to leave a sufficient length of plate without inserting screws at the level of fracture in the bridging technique (atleast 2-3 plate holes). This prevents stress concentration in this segment of plate. Because of this we did not have any plate failure as the plate span length in our study was maintained adequate.

The fractures treated with MIPO technique showed healing by secondary fracture union and we noted a early solid bony union in these fractures (except in one case) which corresponds well with the results in biological fixation, this technique being the most recent. We had a mean fracture union at 20 weeks for these cases. From this we can hint that implants can be removed early in these cases.

We evaluated our results and compared them with those obtained by various other studies utilizing different modalities of treatment. Our analysis is as follows.

\section{Age Distribution}

Fractures of the distal tibia are commonly seen in old age. The average age in our series was 49.4 years with the maximum number of patients in $6^{\text {th }}$ decade. 
Table 1: Age distribution in various studies

\begin{tabular}{|c|c|c|}
\hline Study & Total no. of patients in study & Average age \\
\hline T W Lau et al. (2008) & 48 & 51 \\
\hline Abid Mustaq et al. (2009) ${ }^{[36]}$ & 21 & 51 \\
\hline Tomas Borg et al. (2004) & 21 & 41 \\
\hline David L Helfet et al. (1997) ${ }^{[38]}$ & 20 & 43 \\
\hline Nicola Maffulli et al. (2004) ${ }^{[39]}$ & 20 & 47.9 \\
\hline Redfern D J et al. (2004) ${ }^{[40]}$ & 20 & 38.3 \\
\hline E Hasenboehler et al. (2007) ${ }^{[41]}$ & 32 & 45 \\
\hline S Hazarika et al. $(2006)^{[42]}$ & 20 & 44.7 \\
\hline Present study (2010) & 23 & 49.4 \\
\hline
\end{tabular}

\section{Sex Distribution}

There was a male preponderance in the present study with $31(89 \%)$ of the patients being males.

Table 2: Sex distribution in various studies

\begin{tabular}{|c|c|c|c|}
\hline Study & $\begin{array}{l}\text { Total no. of patients in } \\
\text { study }\end{array}$ & M:F ratio & Percentage of males \\
\hline T W Lau et al. (2008) ${ }^{[35]}$ & 48 & $24: 24$ & 50 \\
\hline Abid Mustaq et al. (2009) ${ }^{[36]}$ & 21 & $14: 7$ & 66.6 \\
\hline Tomas Borg et al. (2004) ${ }^{[37]}$ & 21 & $17: 4$ & 80.9 \\
\hline David L Helfet et al. (1997) ${ }^{[38]}$ & 20 & $7: 13$ & 35 \\
\hline Nicola Maffulli et al. (2004) ${ }^{[39]}$ & 20 & $9: 11$ & 45 \\
\hline Redfern D J et al.(2004) & 20 & $16: 4$ & 80 \\
\hline E Hasenboehler et al. (2007) [ [1] & 32 & $26: 6$ & 81.2 \\
\hline S Hazarika et al. $(2006)^{[42]}$ & 20 & $16: 4$ & 80 \\
\hline Present study (2010) & 23 & $15: 8$ & 65.2 \\
\hline
\end{tabular}

\section{Mode of Injury}

Majority of the fractures were sustained due to fall from ground level i.e. $12(52.1 \%)$ patients.

Table 3: Mode of injury seen in various studies

\begin{tabular}{|c|c|c|}
\hline Study & $\begin{array}{c}\text { Total no. of patiens in } \\
\text { study }\end{array}$ & Commomest mode of injury \\
\hline T W Lau et al. (2008) ${ }^{[35]}$ & 48 & RTA \\
\hline Abid Mustaq et al. (2009) ${ }^{[36]}$ & 21 & Fall \\
\hline Tomas Borg et al. (2004) ${ }^{[37]}$ & 21 & Fall \\
\hline David L Helfet et al. (1997) ${ }^{[38]}$ & 20 & Fall \\
\hline Redfern D J et al. (2004) ${ }^{[40]}$ & 20 & Fall \\
\hline S Hazarika et al. $(2006)^{[42]}$ & 20 & Fall \\
\hline Present study (2010) & 23 & Fall \\
\hline
\end{tabular}

\section{Type of Fracture}

All the fractures in our study were of AO type 43A

Table 4: Commonest type of fracture in various studies

\begin{tabular}{|c|c|c|c|c|}
\hline Study & $\begin{array}{c}\text { Total no. of patients in } \\
\text { study }\end{array}$ & $\begin{array}{c}\text { Commonest type } \\
\text { of fracture }\end{array}$ & No. of cases & Percentage \\
\hline T W Lau et al. (2008) ${ }^{[35]}$ & 48 & $43 \mathrm{~A}$ & 25 & 52 \\
\hline Abid Mustaq et al. (2009) [36] & 21 & $43 \mathrm{~A}$ & 14 & 66.6 \\
\hline David L Helfet et al. (1997) ${ }^{[38]}$ & 20 & $43 \mathrm{~A}$ & 12 & 60 \\
\hline Nicola Maffulli et al. (2004) ${ }^{[39]}$ & 20 & $43 \mathrm{~A}$ & 15 & 75 \\
\hline Redfern D J et al. (2004) ${ }^{[40]}$ & 20 & $43 \mathrm{~A}$ & 10 & 50 \\
\hline S Hazarika et al. $(2006)^{[42]}$ & 20 & $43 \mathrm{~A}$ & 10 & 50 \\
\hline Present study (2010) & 23 & $43 \mathrm{~A}$ & 23 & 100 \\
\hline
\end{tabular}

\section{Fracture Union}

All fractures in our series united with 2(8.69\%) fractures going for mal-union of which 1 fracture united at 28 weeks and the other united at 38 weeks. Mean time to union of fracture was 18.9 weeks. 
Table 5: Fracture union rate obtained in various studies

\begin{tabular}{|c|c|c|c|c|c|c|}
\hline Study & $\begin{array}{c}\text { Total no. of } \\
\text { patients }\end{array}$ & $\begin{array}{c}\text { Delayed } \\
\text { union }\end{array}$ & Malunion & Nonunion & $\begin{array}{c}\text { Overall } \\
\text { union }\end{array}$ & $\begin{array}{c}\text { Average } \\
\text { time(weeks) }\end{array}$ \\
\hline T W Lau et al. (2008) ${ }^{[35]}$ & 48 & $5(10 \%)$ & -- & -- & $100 \%$ & 18.7 \\
\hline Abid Mustaq et al. (2009) ${ }^{[36]}$ & 21 & $1(4.7 \%)$ & -- & $1(4.7 \%)$ & $95.2 \%$ & 22 \\
\hline Tomas Borg et al. (2004) ${ }^{[37]}$ & 21 & $2(9.5 \%)$ & -- & $2(9.5 \%)$ & $90.47 \%$ & 15 \\
\hline Redfern D J et al. (2004) ${ }^{[40]}$ & 20 & -- & $1(5 \%)$ & -- & $100 \%$ & 23 \\
\hline E Hasenboehler et al. (2007) ${ }^{[41]}$ & 32 & -- & -- & $2(6.25 \%)$ & $93.7 \%$ & 24 \\
\hline S Hazarika et al. (2006) [ ${ }^{42]}$ & 20 & -- & -- & $2(10 \%)$ & $90 \%$ & 23 \\
\hline Present study (2010) & 23 & $2(8.69 \%)$ & -- & -- & $100 \%$ & 18.9 \\
\hline
\end{tabular}

\section{Overall Results}

We had $20(86.8 \%)$ patients with excellent and good results out of 23 patients in our series. Detailed analysis of function of the patient was done on the basis of KLEMM and BORNER functional assessment, 1986.

Table 6: Overall results obtained in various studies

\begin{tabular}{|c|c|c|c|}
\hline Study & $\begin{array}{c}\text { Total no. of } \\
\text { patients }\end{array}$ & Method of treatment & $\begin{array}{c}\text { Excellent / Good } \\
\text { results \% }\end{array}$ \\
\hline Tomas Borg et al. (2004) ${ }^{[37]}$ & 21 & MIPO (LC DCP) & $17(80.9 \%)$ \\
\hline David L Helfet et al. (1997) ${ }^{[38]}$ & 20 & MIPO (Semitubular plate) & $16(80 \%)$ \\
\hline Nicola Maffulli et al. (2004) ${ }^{[39]}$ & 20 & MIPO (DCP/ One third tubular plate) & $13(65 \%)$ \\
\hline Redfern D J et al. (2004) ${ }^{[40]}$ & 20 & MIPO (DCP) & $14(70 \%)$ \\
\hline E Hasenboehler et al. (2007) ${ }^{[41]}$ & 32 & MIPO (LCP) & $26(81.2 \%)$ \\
\hline Present study (2010) & 23 & MIPO (LCP) & $20(86.8 \%)$ \\
\hline
\end{tabular}

\section{Complications}

\section{Delayed union (2)}

In our study we had 2 cases, both were at the level of distal tibial diaphysis which was fixed with internal fixator principle, one united at 28 weeks and the other at 38 weeks, with primary fracture union, indicating the rigid internal fixation. The cause for the delayed union was probably a small gap at fracture site and the rigidity of fixation without any compression at the fracture site.

\section{Iatrogenic fracture (1)}

This was encountered intra-operatively when an osteoporotic distal tibia fracture was being fixed in an elderly lady. It occurred while a regular cortical screw was being fixed to achieve compression. The friction created between the bone and the plate was the cause for this fracture. We removed the regular screw and inserted a locking head screw. Hence we stabilised the fracture by internal fixator principle.

\section{Superficial infection (2)}

We had two cases of superficial infection which healed with oral antibiotics.

\section{Deep infection (1)}

We encountered one case of deep infection which had abrasion at the fracture site. Patient required open irrigation and closure, followed by IV antibiotics for 2 week.

\section{Conclusion}

We found that the patient sample approximately reflected the regular trauma patients encountered at our set up.

All the fractures eventually united, including 2 cases going in for delayed union.

The anchorage of the locking head screw was found to be excellent even in the osteoporotic bone. Drilling the holes for the locking head screw should always be through a screw-in drill sleeve.

While bridging a fracture, care must be taken to select a strong plate and leave atleast 2-3 plate holes, without inserting screws, over the fracture. This prevents stress concentration and achieves an elastic fixation which is very essential for secondary fracture union.

The LCP when used as an internal fixator for simple fractures it gives a rigid fixation, which is very crucial in treating nonunions.

Fractures treated with MIPO, healed rapidly by secondary fracture union and hence achieving strong bony union across the facture at a much earlier time compared to conventional compression plating. This could suggest the possibility of earlier removal of implant.

We also found that LCP is as good as any conventional plate in providing compression osteosynthesis, but the cost factor has to kept in mind.

Thus we conclude that the Locking Compression Plate system with its various types of screws offers a wide range of possible applications, including difficult fracture situations.

But this also involves the risk and errors that may occur during pre-operative planning as well as intra operatively, until one gets familiar with its biomechanical behaviour and guiding principles.

\section{Refreezes}

1. Sommer C, Gautier E, Muller M, Helfet DL, Wagner M. First clinical results of locking compression plate (LCP). Injury, 2003 Sept; 34(suppl 2): B43-54.

2. Gustillo RB. Fractures of the tibia and fibula. Chapter-27, Fractures and dislocations, Edt. Gustillo RB., Kyle RF., and Templemen DC., Mosby, Philadelphia, 1992, 901.

3. Watson-Jones R, Coltart WD. Slow union of fractures in a study of 804 fractures of the shaft of the tibia and femur". J Bone Joint Surg, 1942, 30:260.

4. Charnley J. Fractures of the shaft of the tibia". The closed treatment of common fractures, Edinburgh, Churchill Livingstone, 1961, 209-249.

5. Dehne Metzcw E, Deffer PA, et al. Non operative treatment of the fractured tibia by immediate weight bearing. J. Trauma, 1961, 1:514.

6. Sermiento A. "Functional below knee cast for tibial 
fracture”. J Bone joint Surg (AM), 1967, 49:855.

7. Nicoll EA. Fractures of the tibial shaft. A survey of 705 cases". J Bone Joint Surg. 1964; 46B:373-387.

8. Anderson LD, Hutchens WC, Wright PE, Disney JM. Fractures of the tibia and fibula treated by casts and transfixing pins. Clin Orthop. 1974; 105:179-191.

9. Bagby GW. Compression bone plating: Historical considerations. J Bone Joint Surg Am. 1977; 59$\mathrm{A}(5): 625-31$.

10. Broos PLO, Sermon A. From unstable internal fixation to biological osteosynthesis. Historical review of operative fracture treatment. Review. Acta Chir Belg, 2004; 104:396-400.

11. Schatzker J. Principles of internal fixation. In: Schatzker $\mathrm{J}$, Tile $\mathrm{M}$, editors. The rationale of operative fracture care. $3^{\text {rd }}$ edn. Berlin, Germany: Springer, 2005, 3-31.

12. Frigg R. Locking compression plate (LCP). An osteosynthesis plate based on the dynamic compression plate and the point contact fixator (PC-Fix). Injury. 2001 Sept; 32(suppl 2): B63-6.

13. Abdel-Aa Am, Farouk OA, Elsayed A, Said HG. The use of locked plate in the treatment of un-united femoral shaft fractures. J Trauma, 2004; 57(4): 832-6.

14. Gonzailez HY, Martan DA, Sainchez JF, Erasun RC. Early results with the new internal fixator systems LCP and LISS: prospective study. Acta Orthop Belg. 2007; 73(1):60-9.

15. Leung F, Chow SP. Locking compression plate in the treatment of forearm fractures: a prospective study. J Orthop Surg. 2006; 14(3):291-4.

16. Smith SR, Bronk JT, Kelly PJ. Effect of fracture fixation on cortical blood flow. J Orthop Res. 1990; 8(4):471-8.

17. Davis TRC, Wood MB. Bone blood flow. In: Wood MB, Gilbert A, editors. Microvascular bone reconstruction. London, UK: Martin Duntiz, 1997, 13-7.

18. Ellis $H$. The speed of healing after fracture of the tibial shaft". J Bone Joint Surg. 1958; 40B:42-46.

19. Gustillo RB., Anderson JT. Prevention of infection in the treatment of one thousand and twenty-five open fractures of long bones. Retrospective and prospective analysis". J Bone Joint Surg. 1976; 58A:453-458.

20. Gustillo RB, Merkow RL, Templeman D. Current concepts review the management of open fractures". J Bone Joint Surg. 1990; 72A299-304.

21. Muller ME, Nazarian S, Koch P, Schatzker J. The comprehensive classification of fractures of long bones. Berlin: Springer-Verlag, 1990.

22. Ruedi TH, Border RJU, Allgower M. Classification of soft tissue injuries". In manual of internal fixation, techniques recommended by the AO-ASIF group, $3^{\text {rd }}$ Edn., Edt., Muller ME., and Allgower M., Springer Verlag, New York, 1990, 151.

23. McKibbin B. The biology of fracture healing in the long bones. J Bone Joint Surg Br. 1978; 60-B:150-62.

24. Atkins RM/ The musculoskeletal system. In: Duthie RB, Bentley R, editors. Mercer's orthopaedic surgery. $9^{\text {th }}$ edn. London, UK: Arnold, 2003, 43-144.

25. Olerud S, Danckwardt-Lillestrom G. Fracture healing in compression plate osteosynthesis. Acta Orthop Sand, 1971; suppl 1.

26. Olerud S, Danckwardt-Lillestrom G. Fracture healing in compression plate osteosynthesis in the dog. J Bone Joint Surg Br. 1968; 50-B(4):844-51.

27. Danis R. The aim of internal fixation. Clin Orthop, 1979 Jan; 138: 23-5.
28. Krettek C, Gosling T. Principles of internal fixation. In: Bucholz RW, Heckman JD, Court-Brown CM, editors. Rockwood and Green's fractures in adults. $6^{\text {th }}$ edn. Philadelphia, USA: Lippincot Williams and Wilkins, 2006, 209-56.

29. Perren SM. The evolution of internal fixation of long bones fractures, the scientific basis of biological internal fixation: choosing a new balance between stability and biology.Review. J Bone Joint Surg Br. 2002; 84B(8):1093-110.

30. Hidaka S, Gustilo RB. Refracture of bones of forearm after plate removal. J Bone Joint Surg Am. 1984; 66(8):1241-43.

31. Perren SM. Evolution and rationale of locked internal fixator technology. Introductory remarks. Injury, 2001 Sept; 32(suppl 2)

32. Wagner M. General principles for the clinical use of LCP. Injury. 2003; 34(suppl 2):B31-42.

33. Perren SM. Backgrounds of the technology of internal fixators. Injury, 2003; 34(suppl2):B1-3.

34. Klemm KW, Borner Martin. "Interlocking nailing of complex fractures of the femur and tibia". Clinc Orthop. 1986; 212:89-100.

35. Lau TW, Leung F, Chan CF, et al. Wound complications of minimally invasive plate osteosynthesis in distal tibia fractures. Int orthop. 2007; 16:697-703.

36. Abid Mushtaq, Rizwan Shahid, Muhammad Asif, Mohammad Maqsood. Distal Tibial Fracture Fixation with Locking Compression Plate (LCP) Using the Minimally Invasive Percutaneous Osteosynthesis (MIPO) Technique. Eur J Trauma Emerg Surg. 2009; 2:159-164.

37. Borg T, Larsson S, Lindsjo U. Percutaneous plating of distal tibial fractures. Preliminary results in 21 patients. Injury. 2004; 35(6):608-614

38. Helfet DL, Shonnard PY, Levine D, Borrelli J. Minimally invasive plate osteosynthesis of distal fractures of the tibia. Injury. 1997; 28(Suppl 1):A42-A48

39. Maffulli N, Toms AD, McMurtie A, Oliva F Percutaneous plating of distal tibial fractures. Int Orthop. 2004; 28(3):159-162

40. Redfern DJ, Syed SU, Davies SJ. Fractures of the distal tibia: minimally invasive plate osteosynthesis. Injury. 2004; 35(6):615-620,

41. Hasenboehler E, Rikli D, Babst R. Locking compression plate with minimally invasive plate osteosynthesis in diaphyseal and distal tibial fracture: a retrospective study of 32 patients. Injury. 2007; 38(3):365-70.

42. Hazarika S, Chakaravarthy J, Cooper J. Minimally invasive locking plate osteosynthesis for fractures of distal tibia - results in 20 patients. Injury 2006; 37(9):877-87. 